UDC 930.2:329.73(477)"1920/1980"

DOI 10.24919/2519-058X.20.240030

\title{
Yaroslav ANTONIUK
}

PhD hab. (History), Employee of the Sectoral State Archive of the Security Service of Ukraine, 7 Zolotovoritska, Kyiv, Ukraine, postal code 01601 (history.volyn@gmail.com)

ORCID: 0000-0002-9419-5990

\section{Liliya TROFYMOVYCH}

PhD (History), Associate Professor, Professor of Department of Humanities of Hetman Petro Sahaidachnyi National Army Academy, 32 Heroiv Maidanu, Lviv, Ukraine, postal code 79012 (l.trofymovych@hotmail.com)

ORCID: 0000-0003-2393-9128

ResearcherID: G-7432-2019

Scopus Author ID: 57188972302

\section{Ярослав АНТОНЮК}

доктор історичних наук, співробітник Галузевого державного архіву Служби безпеки України, вул. Золотоворітська, 7, м. Київ, Україна, індекс 01601 (history.volyn@gmail.com)

\section{Лілія ТРОФИМОВИЧ}

кандидат історичних наук, дочент, професор кафедри гуманітарних наук Національної академії сухопутних військ імені гетьмана Петра Сагайдачного вул. Героїв Майдану, 32, м. Львів, Україна, індекс 79012 (l.trofymovych@hotmail.com)

Bibliographic Description of the Article: Antoniuk, Y. \& Trofymovych, L. (2021). The Usage of the Open Sources Information by the Special Units of the Ukrainian Nationalist Organisations in the 1920s - 1980s. Skhidnoievropeiskyi Istorychnyi Visnyk [East European Historical Bulletin], 20, 116-126. doi: 10.24919/2519-058X.20.240030

\section{THE USAGE OF THE OPEN SOURCES INFORMATION BY THE SPECIAL UNITS OF THE UKRAINIAN NATIONALIST ORGANIZATIONS IN THE 1920s - 1980s}

\footnotetext{
Abstract. The purpose of the study is to highlight the intelligence activities based on open sources by special units of the Ukrainian nationalist organizations in the 1920s-1980s. The principles of scientific objectivity and historicism are the methodological basis of the research. The scientific novelty of the obtained results consists in the following: for the first time in domestic and foreign historiography the intelligence activities of special units of the Ukrainian nationalists have been analyzed on the basis of open sources, the unpublished archival materials have been introduced into a scientific circulation as well. The Conclusions. The intelligence departments of the Ukrainian Military Organization (UMO) began the collection, compilation and analysis of the enemy's press in various languages by the special units of the Ukrainian nationalist organizations for the first time during the 1920s.

During the 1930s, intelligence of the Ukrainian Nationalists Organization (OUN) learned about the repressions in the USSR from the Soviet and Polish newspapers. After the German-Soviet annexation of Poland, the Security Service (SS) of the OUN was engaged in this work. During the post-war period,
} 
the Security Service focused on district and regional Soviet newspapers. From the newspapers the SS learned about the death or capture of underground fighters, planned measures of the Soviet government, identified the enemy active supporters among the local population.

The OUN Foreign Units (FU) played a particularly important role in obtaining and analyzing the Soviet publications. To know about the situation in the USSR, "Referentura of Countries Affairs, which were under the Soviet Rule" ("RCAUSR") was established in Munich at the end of September of 1953. Due to a lack of funds and the necessary specialists, it was dissolved in 1968 and its functions were transferred to the Ukrainian Information Service (UIS) in London.

Conducting surveys of the civilian population was one of the types of getting intelligence information by special units of the Ukrainian nationalist organizations.

The OUN special units in Western countries used journalistic cover-ups or correspondence with relatives in the USSR and the Warsaw Treaty (the Warsaw Pact) countries to conduct covert surveys. At the beginning of the 1960s, the "offensive" departments were established in the structure of "The Central" and Field Leadership of the OUN SS FU, which were responsible for survey the Soviet tourists and employees of international institutions of the Ukrainian SSR. In addition, the "offensive" department of the OUN SS FU, as well as "The Public Guardianship Referentura", interviewed Western tourists who visited the USSR.

Simultaniously with the "offensive" departments of the OUNSS FU, the "analytical and intelligence group" of the Foreign Representation of the Ukrainian Chief Liberation Council and the "dviykari" intelligence collected and analyzed the Soviet open sources of intelligence information.

Key words: intelligence, open sources, periodicals, offensive departments, OUN, SS, FU OUN, RCAUSR, UkrSSR, survey, KGB.

\section{ВИКОРИСТАННЯ СПЕЦІАЛЬНИМИ ПІДРОЗДІЛАМИ УКРАЇНСЬКИХ НАЦІОНАЛІСТИЧНИХ ОРГАНІЗАЦІЙ ВІДКРИТИХ ДЖЕРЕЛ ІНФОРМАЦЇ̈ У 1920 - 1980-х рp.}

\footnotetext{
Анотація. Мета досліджсенн - висвітлити здійснення спеціальними підрозділами українських націоналістичних організацій у 1920 - 1980-х рр. розвідувальної діяльності на основі відкритих джерел. Методологічною основою дослідження стали приниипи наукової об'єктивності та історизму. Наукова новизна одержаних результатів полягає y тому, щзо вперше у вітчизняній $i$ зарубіжній історіографії проаналізована розвідувальна діяльність специпідрозділів українських націоналістів на основі відкритих джерел, а також упроваджено до наукового обігу неопубліковані архівні матеріали. Висновки. Уперше з-поміж спеціальних підрозділів украӥнських націоналістичних організаџій збір, впорядкування й аналіз преси супротивника різними мовами розпочали у 1920-х рр. відділи діловодства розвідки Украӥнської військової організачії (УВО). Протягом 1930-х рр. розвідка Організації украӥнських націоналістів (ОУН) дізнавалася з радянських та польських газет про репресії в УРСР. Після німеиько-радянської анексї Польщі зазначеною роботою займалася Служба безпеки (СБ) ОУН. У післявоєнний період головна увага есбістів зосередилася на районних та обласних радянських газетах. Із них вони дізнавалися про загибель або потрапляння до полону підпільників, заплановані заходи радянської влади, виявляли активних прибічників ворога серед місиевого населення.

Особливо важливу роль здобуттю й аналізу радянських видань приділяли Закордонні частини (3Ч) ОУН. Спеціально для вивчення ситуаиії в СРСР наприкінці вересня 1953 р. у Мюнхені було створено “Референтуру Підсовєтських Справ" (“РПС”). Через нестачу коштів та необхідних фахівиів у 1968 р. вона була розформована, а ї̈ функиії перейшли до Украӥнської інформачійної служби (УІС) у Лондоні.

Одним із різновидів збору розвідувальної інформації спеціальними підрозділами украӥнських націоналістичних організацій було опитування циивільного населення. Для негласного опитування спеціальні підрозділи ОУН в країнах Заходу використовували журналістське прикриття або листування з родичами в СРСР та країнах Вариавського договору. На початку 1960-х рр. при “Централі" та Тереновому проводі СБ ЗЧ ОУН було створено “офензивні" відділи, які відповідали за опитування радянських туристів та співробітників міжнародних установ УРСР. Крім того, “офензивний” відділ СБ ЗЧ ОУН, а також референтура "Суспільної опіки” займалися опитуванням західних туристів, які відвідували СРСР.

Паралельно з “офензивними” відділами СБ ЗЧ ОУН збором і аналізом відкритих радянських джерел інформації займалася “аналітично-розвідувальна група”” Закордонного Представництва Української Головної Визвольної Ради та розвідка “двійкарів”.

Ключові слова: розвідка, відкриті джерела, періодика, офензивні відділи, ОУН, СБ, ЗЧ ОУН, РПС, УРСР, опитування, КДБ.
} 
The Problem Statement. The opening of the archives of the Soviet secret services in Ukraine, combined with the dynamic development of information technology in a relatively short period of time, raised historical researches to a qualitatively new level. Preconditions emerged for the study of previously unknown aspects of important scientific problems. One of these preconditions is the intelligence activities on the basis of open source intelligence (OSINT) by special units of the Ukrainian nationalist organizations. With the development of information technology, the role of open source intelligence is growing in all intelligence services around the world.

The Analysis of Recent Researches and Publications. There is no publication directly related to this topic currently. Oleksandr Sych and Hennadiy Ivanushchenko studied some of its aspects. However, this is for the first time that comprehensive work on the intelligence activities of special units of the Ukrainian nationalist organizations has been carried out on the basis of open source intelligence.

The Main Material Statement. The collection and analysis of open source intelligence information always played an important role in the intelligence activities of special units of the Ukrainian nationalist organizations. During the 1920s, one of the tasks of the 1st departments of the "Intelligence Bureaus" (IB) of the UMO was to learn about the enemy based on the press publications. All received newspapers and magazines were added to the "evidence" book. During the registration the newspapers and magazines were classified into "domestic" (written in Ukrainian) and "foreign" (written in foreign languages) (National Archives Czech Republik (NACR), f. 1659, d. 20, c. 538, pp. 16-17). For example, the 1st Department (Office) of "The Central Intelligence Bureau" ("CIB") UMO made press excerpts: from the Soviet newspapers ("Izvestiya" (Moscow), "Pravda" (Moscow), "Ekonomicheskaya Zhyzn" (Moscow), "Visti" (Kharkiv), "Bilshovyk" (Kyiv), "Chervona Armiya" (Kyiv)); from the newspapers of the Russian emigration ("Rul” (Berlin), "Dni”" (Berlin), "Posledniye Novosti" (Paris), "Za Svobody!” (Warsaw)); from Warsaw press ("Rzeczpospolita", "Polska Zbrojna”, "Robotnik", "Kurier Warszawski", "Kurier Poranny", "Przegląd Wieczorny", "Kurier Polski”, “Żołnierz Polski”, "Gazeta Warszawska", "Nasz Przegląd”); from the newspapers of other cities in Poland ("Kurier Lwowski” (Lviv), "Kurier Poznański” (Poznań), "Słowo" (Vilnus), "Dziennik Wileński" (Vilnus)); from the free city of Danzig (Gdansk) ("Gazeta Gdańska", "Baltische Presse") (NACR, f. 1659, d. 24, c. 559, p. 215).

In the 1930s, this activity was continued by the OUN intelligence referentura. Antin Krushelnytsky, a writer, wrote that most of the information about the events in the Ukrainian SSR, including repressions, the OUN members learned about from the Polish newspapers. Journalists often received the information from embassy staff. Another important source of information was the Soviet newspapers, which published the names of the convicts and their sentences (Sectoral State Archive of the Security Service of Ukraine (SSA SSU), f. 5, d. 1, c. 47932, vol. 2, p. 126). During the years of 1940 - 1941, the OUN Security Service analyzed the enemy's newspapers, magazines, and books at the territory of the GovernorGeneral's. Thus, Yuri Sokolovsky ("Utio") secretly brought the Soviet military documents, statutes, manuals and periodicals across the border from Lviv to the town of Sanok. (Knysh, the year is not marked, p. 136).

During the period of the German occupation, the collection of intelligence information from open sources became even more developed. The SS staff not only analyzed the legal and illegal press (in German, Russian, Polish, Romanian and other languages), but also all available radio broadcasts. For example, Bohdan Yavorsky ("Director"), a clerk in the SS of Odesa regional branch of the OUN, studied and summarized the data from the local 
Russian-language and Romanian press in the summer of 1943. Volodymyr Stelmashchuk ("Yurko"), a head of intelligence of the OUN Buchach district, received "Biuletyn Ziemi Czerwieńskiej" (Lviv) and "Biuletyn Informacyjny" (Warsaw) from agents periodically. Petronia Zeleniuk, a head of the Security Intelligence Network in Lviv ("Myroslava") added to the information reports the data from the Polish newspapers at the beginning of 1944. Anna Ivasiuk ("Romashka"), a spy of the Security Service of Lviv city branch of the OUN, noted radio messages at the beginning of 1944 (Archive of Department of the Security Service of Ukraine in Lviv region, f. 5, c. 13359, p. 231; Archive of Department of the Security Service of Ukraine in Odessa region, f. 6, c. 25307, vol. 3, p. 139; SSA SSU, f. 6, d. 1, c. 75592, p. 28; c. 74327 , vol. 1 , p. 145 ; c. 76079 , pp. 51-54).

During the post-war period, the SS attention was focused on the Soviet press again. It was focused on district and regional newspapers especially. Georgy Bandusiak ("Lys"), a Security Service officer of the Transcarpathian Command of the OUN, did this work in May of 1945 (Archive of Department of the Security Service of Ukraine in Zakarpattia region, f. 7, c. 5678, vol. 1, p. 123). On April 1, 1946 the magazines "The Soviet Ukraine", "Pravda Ukrayiny" as well as the latest issues of regional and district newspapers were found in the kryivka of the district officer of the SS during the search by operative group of Velykomostivsky regional department of the Ministry of State Security (MSS) of the Ukrainian SSR (SSA SSU, f. 71, d. 9, c. 162, p. 102). Analyzing the press, the Security Service learned about the planned activities of the authorities, the death or capture of underground fighters, identified active supporters of the enemy among the local population. In the report of the Office of the People's Commissariat of State Security (NKDB) of Lviv region of February 19, 1945, it was stated that the esbists (the SS) clarified certain facts from the Soviet newspapers by informants (SSA SSU, f. 71, d. 9, c. 192, p. 101). This information was mentioned at the meeting of the Office of the People's Commissariat of Internal Affairs (NKVD) of Lviv region in August of 1945 (SSA SSU, f. 71, d. 9 , c. 63 , p. 71). In response to the situation, beginning in 1946, the Soviet periodicals kept silent about the underground of the OUN and the Ukrainian Insurgent Army (the UPA).

One of the sources of the enemy newspapers supply for the SS staff was sabotage-terrorist operations. For example, on May 7, 1945, the SS captured special couriers of the NKVD regional department near the city of Pidvolochysk, Ternopil region. The NKVD couriers had a bag with regional and central newspapers (SSA SSU, f. 73, d. 1, c. 469, pp. 113-114). However, the press was mainly supplied to the SS by their informants. For example, a postman Demian Nykolaichuk from the village of Yelne, Klesiv district, Rivne region; Pavlyna Makovska, a collective farmer from the village of Horodok, Zalishchyky district, Ternopil region; Vasyl Davydovych, a resident of the village of Dobrotvir, Kamianka-Buzka district, Lviv region (Archive of Department of the Security Service of Ukraine in Rivne region, f. 5, c. 5440, p. 291; SSA SSU, f. 71, d. 9, c. 244, p. 32; State Archive of the Ternopil region, f. R-3429, d. 1, c. 1603, p. 3). Informants from Busk district of Lviv region supplied the local intelligence officer of the SS with the district newspaper, as well as the regional newspaper "Vilna Ukraina" (SSA SSU, f. 71, d. 9, c. 302, p. 45). The SS intelligence officer of the OUN, Rohatyn district received the Soviet newspapers from informants periodically: "Pravda", "Pravda Ukrainy", "Vilna Ukraina", and Ternopil regional newspaper "Vilne Zhyttia" (SSA SSU, f. 6, d. 1, c. 50213, vol. 1, p. 297). Often these tasks were performed by the SS spies in the Soviet institutions. During the year of 1946 Volodymyr Hevko, a postman of Zastavia village of Velykoborkivskyi district, Ternopil region, supplied boyivka "Sirka" with the press (SSA SSU, f. 73, d. 1, c. 119, pp. 84-85). Yevhenia Obukhovska, an employee 
of Ternopil Regional Press Union in Chortkiv, analyzed the materials received for publication in local newspapers and periodically gave the collected information to Yaroslav Namak, the SS county secretary-referent (“Klym”) (SSA SSU, f. 73, d. 1, c. 39, p. 109; c. 211, pp. 97-98).

"The Ukrainian Information Service" played an important role in the analysis of the Soviet periodicals. On January 31, 1947 during the liquidation of kryivka in the village of Vybudiv, Koziv district, Ternopil region the Soviet newspapers were found by the operative group of the regional department of the State Security Service (SSA SSU, f. 73, d. 1, c. 480, p. 216). In the kryivka-publishing house of the OUN, Kamianets-Podilsky district, the operative group of the State Security Service found the files of the Soviet press of 1948 - 1949. In particular: the magazines "Ogoniok", "Krokodyl", "Rabotnitsa", "Perets", the newspapers "Pravda", "Pravda Ukrainy", "Radianske Selo", "Radianske Podillya" (Archive of Department of the Security Service of Ukraine in Khmelnytskyi region, f. 7, c. 29159, vol. 2, p. 337).

At the end of the 1940s - beginning of the 1950s, the Soviet periodicals became the main source of information for the SS about the Ukrainian lands, which were the part of other republics. Thus, the SS Referentura of Bukovyna district learned about the events in the Moldavian SSR from the Soviet newspapers mainly (SSASSU, f. 5, d. 1, c. 67579, vol. 4, p. 145). The situation was similar in the SS of Kovel district concerning the Byelorussian SSR (Kovalchuk \& Ohorodnik, 2011, p. 522). In addition, the SS staff read the Polish and Czechoslovak periodicals (SSA SSU, f. 62, d. 4, c. 18, p. 9). On the basis of the latter, the SS Referantura of Lemkivsky district "Beskyd" made an analytical brochure covering the period of May - June of 1946 (Institute of National Remembrance Office of Access (INR OA), 1554/66, pp. 21-35). In 1946 the SS staff of Przemyśl district of the OUN "Kholodny Yar" used the articles from the Polish newspapers to prepare "Vistky z Terenu": "Dziennik Polski" of February 1, "Trybun roboczy" of June 10 and "Nowe Horyzonty" of 23 June (SSA SSU, f. 62, d. 4, c. 78, p. 207). Not only the Soviet and Polish newspapers, but also American newspapers were found in the kryivka of Petro Fedoriv ("Dalnych"), the OUN SS secretary-referent (INR OA, 1554/12, pp. 1-94).

Based on the analysis of the Soviet periodicals, the UPA publishing house "Vulkan" published informational "Reprints from Bolshevik Newspapers". One of its issues of 1946 consisted of the press materials: "The Soviet Word" of June 19 (the article "What's Happening in China?"); "Pravda Ukrayiny" of July 27 ("New Masters of the UkrainianGerman Nationalists"); "Vilna Ukrayina" of July 31 ("The Czech Newspaper on the Activities of Fascist Groups in the Western Zones of Occupation of Austria") (INR OA, 1063/85/1, pp. 54-55). The major part of this information could be obtained by listening to and analyzing radio broadcasts. In Osyp Mytsyk's pad ("Donsky"), the SS intelligence officer of Stryi district, who was liquidated on April 30, 1951, the MGB officers found the list of radios that were located in kryivka (SSA SSU, f. 1, d. 1, c. 404, p. 227).

The special units of the OUN FU attached special importance to the collection and analysis of the Soviet periodicals. At the end of the 1940s and the beginning of the 1950s, the SS "Central", located in Munich at 67 Zeppelin Strasse, received the newspapers periodically: the "Pravda", "Ogoniok", "Izvestiya" and "Komsomolskaya Pravda" (SSA SSU, f. 6, d. 1, c. 51997 , vol. 2, p. 134; Ivaniushchenko, 2019, p. 196).

On September 21, 1953, according to the decisions of IV Conference of the OUNFU, Stepan Lenkavsky ("Proffesor"), a member of the "chief link" of the SS, established "Referentura of the Countries Affairs which were under the Soviet Rule" ("RCAUSR") in Munich (MudrykMechnyk, 1984, p. 211). Its leadership included natives of the central, southern and eastern 
regions of the UkrSSR. For example, Andriy Mykulyn (a former Major of the Red Army who came from Argentina) dealt with the army, state apparatus and concentration camps. Marchenko - the Soviet publications, Lysenko - economy, Kizko - culture and religion. The following departments functioned as the part of "RCAUSR": a) information-collection department; b) department for Ukraine and the USSR; c) department for the satellitecountries of the USSR and the communist activity in the world; d) department for the study of liberation and revolutionary movement in Ukraine; e) archives and secretariat department (Sych, 2005, pp. 66-68). The RCAUSR staff not only monitored all changes in the USSR, but also systematized and analyzed the information obtained (Mudryk-Mechnyk, 1984, p. 211). In particular, they drew up detailed reports on the heads of the State Security Committee bodies (KGB) and the party leadership of the Ukrainian SSR, including the regional departments. Similar data were collected concerning the central office in Moscow and even other republics of the Soviet Union (Mudryk-Mechnyk, 1983, pp. 48-50). Information on the detention places of political prisoners was also recorded. A separate identification card was issued for each prison. In one of the cards it was written that there was the KGB "concentration camp" near Kharkiv. In this "concentration camp" there were dissidents, religious preachers and criminals imprisoned (Archive of the Liberation Movement Research Center (ALMRC), f. 23, vol. 6, p. 1). In 1958, based on these data, A. Mykulyn published the book "Concentration Camps in the Soviet Union" (Mykulyn, 1958). During the year of 1960, three brochures marked "for internal organizational use" were published in the "Information Notebooks" of the OUN FU - "On the XXth Congress of the CPSU", "Agriculture in the USSR" and "Concentration Camps in the USSR" (SSA SSU, f. 16, d. 1, c. 0940, p. 27).

In the future, a commissioner of the "RCAUSR" was to be present at each Field Office of the OUN FU, to establish contacts with Western research, social and political institutions that specialized in the studies of the USSR (Sych, 2005, p. 77). For example, the "RCAUSR" cooperated with the Institute for the Study of the History and Culture of the USSR in Munich. Its authors were published in the "Library of the Ukrainian Underground" (Ivaniushchenko, 2019, p. 198; Artemyev, 1956). Stepan Mudryk ("Mechnyk"), the intelligence officer of the OUN SS FU, recollected the fact that there were some problems with other research institutions. The representatives of the Russian emigration mainly, who had a negative attitude to the Ukrainian nationalism, dealt with the direction "The Soviet Studies" in these research institutions (Mudryk-Mechnyk, 1989, p. 73).

At the beginning of the 1960s, the "RCAUSR" experienced a severe crisis. Almost all employees emigrated from the Federal Republic of Germany (Germany) and resigned. In the letter dated July 16, 1962, Andriy Mykulyn reported that only he and Shushyk, a technician, remained from the entire staff. After the year of 1968, eventually, the "RCAUSR" ceased its activity due to lack of funds and necessary specialists (Sych, 2005, pp. 69-70, 76-77).

In the future, the UIS was the main OUN FU center for collecting information from the Soviet open sources. It was located in London: Liverpool Road street, 200. At the same time, in the 1970s - 1980s there was organized the subscription to the Soviet periodicals: "The Moscow News", "The Communist of Ukraine", "The Ukrainian Historical Magazine", "The Economy of the Soviet Ukraine", "The Philosophical Thought", "The Universe", "The Fatherland", "The Kyiv", "The New World", "The Bell”, "The Soviet Military Review", "The Bulletin of the Supreme Soviet of the USSR" and the others. The Soviet books were bought constantly, which were grouped according to the subject: 1) books on history; 2) fiction books; 3) economical books; 4) ideological books; 5) geographical books; 6) legal books. 
Some publications were brought to the UIS by tourists, athletes, and conference participants. This is evidenced by the stamps "Allowed for export from the USSR" (Ivaniushchenko, 2019 , p. 196). Students from "the third world" countries who studied in the Soviet Union were sometimes used for this purpose (SSA SSU, f. 16, d. 1, c. 1073, p. 143). Analytical reports were made on the basis of the collected information. For example, members of the OUN SS came to the conclusion that in March of 1985 Mykhailo Gorbachev took the post of the General Secretary of the CPSU Central Committee with the support of Yuri Andropov and the leadership of the USSR KGB (Mudryk-Mechnyk, 1989, p. 95).

Survey of the civilian population was also a widely spread way of getting information from open sources. The first "questionnaires" appeared in the intelligence of the UMO. Later this practice was continued by the OUN members. On the eve of the sabotage in the summer of 1930, they got information from the local population by means of the "questionnaire" consisting of 28 questions. Among the questions there were the following: are there any police stations, post office, railway station, bridges, schools (Polish or Ukrainian), communists, informers, "khruni" (the authors - traitors) in your residence place? (Wysocki, 2003, p. 266).

During the postwar period, "questionnaires" were used to obtain intelligence data from the eastern regions of Ukraine and other Soviet republics (INR OA, 1554/116, pp. 2-5; SSA SSU, f. 5 , d. 1, c. 68236 , vol. 2, p. 327 ; f. 6 , d. 1 , c. 68811 , v. 1 , p. 128 ; c. 75386 , v. 2 , p. 281). On the basis of the information obtained this way, on October 10, 1946, the staff of the Security Service of Lviv Regional Command of the OUN compiled "The Description of the City of Yaroslavl" (the authors - Yaroslavl city, the Russian SFSR) (SSA SSU, f. 6, d. 1, c. 74268 , v. 2, pp. 125-126). On April 30, 1950, the MGB took away the "questionnaire" consisting of 55 questions from Mykola Mylosh, a teacher from Kyiv region. The OUN SS was interested in the following: the mood of the local population, dissatisfaction with the collective farms, attitude to the Soviet government, the Ukrainian liberation movement, the state of Russification, intolerable working conditions at enterprises, abuse by the Soviet officials and the military (SSA SSU, f. 71, d. 9, c. 270, pp. 80-90; f. 73, d. 1, c. 569, pp. 1-2).

The OUN SS special units were particularly active in getting information by means of secret surveys in the western branches of the Ukrainian diaspora. "The Information Bulletin" of April 9, 1946, published the information from Frankfurt am Main (Hesse, West Germany) on the Soviet repression in Galicia. The information was obtained by interviewing the Jewish emigrants from the western regions of the USSR (INR OA, 1063/85/1, p. 12). Spies of "Political Intelligence Service" often operated under the guise of Western journalists. In 1948 one of them managed to meet with Andriy Gromyko, the Deputy Minister of Foreign Affairs of the USSR Andrei Gromyko, in New York (SSA SSU, f. 6, d. 1, c. 56232, pp. 193-194). Correspondence with relatives in the USSR and the Warsaw Treaty countries (the Warsaw Pact) was a less reliable way of getting information. During the year of 1949, Myron Matvieiko ("Usmikh"), a referent of the OUN SS FU, sent several letters to his cousin, Vasil Davydovych, a priest from the village of Dobrotvir of Kamyanka-Busk district, Lviv region (SSA SSU, f. 71, d. 9, c. 244, p. 33). However, this method of getting information was considered unreliable. Letters were often read by the Soviet secret services, and it lead to repression of relatives or their recruitment.

At the beginning of the 1960s, "offensive" departments were established in the OUN SS FU "Central" and TP (Archive of the Organization of Ukrainian Nationalists at the Ukrainian Information Service - London (AOUNUIS L), f. 1, d. 1, c. 45, p. 106). Their task was to find contact with the Soviet tourists, as well as employees of international institutions of the 
UkrSSR. the "offensive" department staff often sought contact with foreign "colleagues". Specialists in certain fields of science or art who were well acquainted with the situation in the USSR were selected to the "offensive" department staff. They obtained the necessary information during friendly conversations with "colleagues". In addition, the "offensive" department dealt with Western tourists who intended to visit the USSR or the Warsaw Pact countries. Those were Western tourists of not only Ukrainian origin, as they were less closely monitored by the KGB. On the eve of the trip they were given detailed instructions (AOUNUIS L, f. 1, d. 1, c. 44, pp. 74-77).

The OUN FU Referentura of "Public Guardianship" also collected intelligence information from tourists who visited the USSR. The instruction for its heads of the regional level of June 5, 1975 included the recording of personal data (name, surname, address, telephone number, membership in emigrant organizations and societies, having relatives in Ukraine). Tourists were classified into categories: old emigrants, children of old emigrants, new emigrants, the OUN members and their relatives. The latter coordinated their trips with the regional leader and received instructions from him. After each tourist trip, the following issues were clarified: its influence on political views, contacts with the Soviet "statesmen", detention and recruitment by the KGB. All tourist's observations of visits to the USSR were recorded, often on a "tape" (bobin) with the smallest details (AOUNUIS L, f. 1, d. 1, c. 45, pp. 62-63; f. 31, d. 1, c. 52, p. 1). The information received was used by the OUN FU to conduct intelligence surveys, as well as in propaganda work (ALMRC, f. 23, vol. 2, pp. 5-6).

Emigrants from the Warsaw Pact countries of a non-Ukrainian origin were sometimes surveyed by the SS. For example, the SS Chief Ivan Kashuba ("Chad"), intelligence officer Stepan Mudryk ("Mechnyk"), and Volodymyr Lenyk, a head of the Ukrainian Youth Union (UYU) branch, visited the Jewish immigrant center near Rome in May of 1977, and in August of 1981 - the Polish refugee camps near Vienna (Austria), Nuremberg (Bavaria, Germany) and Göttingen (Lower Saxony, Germany) (SSA SSU, f. 16, d. 1, c. 1060, p. 151; c. 1089, pp. 270-271).

Beginning with the 1960s, the practice of publishing questionnaires continued. One of the first was the "Note for Visitors who are back from the Iron Curtain". It consisted of 197 questions for interviews with citizens of the USSR (SSA SSU, f. 16, d. 1, c. 0994, p. 28). In December of 1975, the OUN TP of Canada elaborated a questionnaire for the Soviet citizens abroad. The questions were classified according to the following items: education, personnel policy in higher education, the role of party organizations, place of work, national composition of workers, employees, students, wages, the state of supply of products, industrial goods, the government's response to them shortage, reasons for mass migration of peasants to cities, the party and Komsomol organizations in collective farms (SSA SSU, f. 16, d. 1, c. 1048, pp. 91-92). On June 5, 1984, the KGB of the Ukrainian SSR informed the Central Committee of the Communist Party that the OUN elaborated a new questionnaire for survey of the Soviet citizens abroad. It provided for thematic groups: 1) the Soviet and party members, its national composition; 2) the language of teaching in higher educational institutions of Lviv and Kyiv; 3) the facts of Russification; 4) persecution of the Greek-Catholic priests (SSA SSU, f. 16, d. 1, c. 1105, p. 245). According to the data of the KGB of the Ukrainian SSR dated on April 3, 1985, a new OUN questionnaire was published, which provided additional questions: 1) activity of illegal organizations in Western Ukraine; 2) the number of the Ukrainians among servicemen in the USSR (SSA SSU, f. 16, d. 1, c. 1108, pp. 231-232).

The "analytical and intelligence group" of the Foreign Office of the Ukrainian General Liberation Council (FOUGLC), established on January 24, 1971 by the decision of the Great 
Congress in New York, also collected and analyzed open sources of information. Its work was carried out in the following areas: 1) survey of the Soviet citizens; 2) getting information by correspondence with relatives in the USSR and the Warsaw Pact countries; 3) cooperation with American journalists who were accredited in the USSR (SSA SSU, f. 16, d. 1, c. 0991, pp. 83-85). In March of 1971, the questionnaire entitled "They Don’t Believe You" was published by "dviykari". The Soviet citizens were classified into "reliable", "honest people" and "activists of the Soviet party organizations" (SSA SSU, f. 16, d. 1, c. 0993, p. 238). There was warning written in the questionnaire: every Soviet citizen must be checked by the KGB before leaving for abroad (SSA SSU, f. 16, d. 1, c. 0999, pp. 16-28; ALMRC, f. 23, vol. 7, p. 1).

The Conclusions. For the first time among the special subdivisions of the Ukrainian nationalist organizations, the collection, organization, and analysis of the enemy's press in various languages began in the 1920s by the UMO intelligence departments. During the 1930s, the OUN intelligence learned from the Soviet and Polish newspapers about repression in the USSR. In particular, the names of convicts and sentences against them. After the GermanSoviet annexation of Poland, the Security Service was engaged in this work. Illegally its staff sent various military documents and enemy periodicals across the border from the western regions of the Ukrainian SSR to the Governor-General's Office. In the spring of 1943, the collection of intelligence information from open sources by the Security Service became even more developed. Analysis of press and radio broadcasts in German, Russian, Polish, Romanian and other languages was performed. During the postwar period, the SS focused on the Soviet district and regional newspapers. From them they learned about the death or capture of underground fighters, planned measures of the Soviet government, identified active supporters of the enemy among the local population, events in the Ukrainian lands of the Moldavian SSR and the Byelorussian SSR. The SS informants supplied periodicals.

The OUN FU played a particularly important role in getting and analyzing the Soviet publications. They subscribed to the majority of periodicals legally. To study the situation in the USSR, the "Referentura of the Countries Affairs which were under the Soviet Rule" ("RCAUSR") was established in Munich at the end of September of 1953. Each of its employees was assigned a specific thematic group: the army, the state apparatus, places of detention, publications, economy, culture and religion. On the basis of the obtained information, card indexes were compiled and brochures on the situation in the USSR were published. To analyze the data, cooperation was established with research institutions in the West. Due to a lack of funds and the necessary specialists, the RCAUSR was dissolved in 1968 and its functions were transferred to the UIS in London.

Survey of the civilian population was one of the types of getting intelligence information by special units of the Ukrainian nationalist organizations. For the first time, this method was used by the UMO intelligence in the form of "questionnaires". This practice was continued by the OUN during the 1930s and at the beginning of the 1950s. Questionnaires were used to collect information on enemy troops, officials, strategic objects, public mood, abuse, and suspects.

The OUN special forces in the West used journalistic cover-ups or correspondence with relatives in the USSR and the Warsaw Pact countries to conduct covert surveys. At the beginning of the 1960s, "offensive" departments were set up at the "Central" and the OUN TP SS FU, which were responsible for interviewing the Soviet tourists and employees of international institutions of the Ukrainian SSR. It selected specialists in certain types of science who could be trusted were selected to its staff. In addition, the "offensive" department of the OUN SS FU, as well as the "Public Guardianship Referentura", interviewed Western 
tourists who visited the USSR. Special "questionnaires" were published for the work, and stories were often recorded on a magnetic tape. Sometimes the respondents were citizens of the USSR or the Warsaw Pact countries of a non-Ukrainian origin - the Jews, the Poles, the Czechs, the Slovaks, the Russians, etc.

Simultaniously with the "offensive" departments of the OUN SS FU, during the 1970s the "analytical and intelligence group" of the FOUGLC and the "dviykari" intelligence collected and analyzed the Soviet open sources of information.

Acknowledgement. We express sincere gratitude to all members of the editorial boardfor consultations provided during the preparation of the article for printing.

Funding. The authors received no financial support for the research, authorship, and/orpublication of this article.

\section{BIBLIOGRAPHY}

Arkhiv Orhanizatsii Ukrainskykh Natsionalistiv $v$ Ukrainskii Informatsiinii Sluzhbi-London [Archive of the Organization of Ukrainian Nationalists at the Ukrainian Information Service - London-AOUNUIS L]

Arkhiv Tsentru doslidzhen vyzvolnoho rukhu [Archive of the Liberation Movement Research Center-ALMRC]

Arkhiv Upravlinnia Sluzhby Bezpeky Ukrainy u Khmelnytskii oblasti [Archive of Department of the Security Service of Ukraine in Khmelnytskyi region - ADSSU KhR]

Arkhiv Upravlinnia Sluzhby Bezpeky Ukrainy u Lvivskii oblasti [Archive of Department of the Security Service of Ukraine in Lviv region-ADSSU LR]

Arkhiv Upravlinnia Sluzhby Bezpeky Ukrainy $v$ Odeskii oblasti [Archive of Department of the Security Service of Ukraine in Odessa region - ADSSU OR]

Arkhiv Upravlinnia Sluzhby Bezpeky Ukrainy $v$ Rivnenskii oblasti [Archive of Department of the Security Service of Ukraine in Rivne region-ADSSU RR]

Arkhiv Upravlinnia Sluzhby Bezpeky Ukrainy $v$ Zakarpatskii oblasti [Archive of Department of the Security Service of Ukraine in Zakarpattia region - ADSSU ZR]

Artemyev, V. (1956). Rezhiym i okhrana ispravitelno-trudovikh lagerei MVD [The regime and security of correctional labor camps of the Ministry of Internal Affairs]. Miunkhen: Institut po izucheniiu SSSR, 217 p. [in Russian]

Derzhavnyi arkhiv Ternopilskoi oblasti [State Archive of Ternopil region-SATR]

Haluzevyi derzhavnyi arkhiv Sluzhby bezpeky Ukrainy [Sectoral State Archive of the Security Service of Ukraine - SSA SSU]

Instytut Pamięci Narodowej Biuro Udostępniania [Institute of National Remembrance Office of Access - INR OA]

Ivaniushchenko, H. (2019). Radianski vydannia v bibliotetsi Arkhivu OUN yak dzherelo doslidzhennia antyradianskoi kontrpropahandy OUN [The Soviet Publications in the Library of the Archive of the Organization of the Ukrainian Nationalists as a Source of Research on Anti-Soviet Counter-Propaganda of the OUN]. Pravova nauka i derzhavotvorennia v Ukraini v konteksti pravovoi intehratsii [Legal science and strengthening of statehood in Ukraine in the context of legal integration]: materialy XII Mizhnarodnoi naukovo-praktychnoi konferentsii (pp. 194-199). Sumy. [in Ukrainian]

Knysh, Z. (without year). Pered pokhodom na Skhid. Spohady i materiialy do diyannia Orhanizatsii Ukrainskykh Natsionalistiv u 1939 - 1941 rokakh [Before the March to the East. Memories and Materials about the Activity of the Organization of the Ukrainian Nationalists in 1939-1941]. (Vol. 1). Toronto: Sribna Surma, 187 p. [in Ukrainian]

Kovalchuk, V. \& Ohorodnik, V. (Comps.). (2011). Litopys UPA. Nova seriia. [Chronicle of the UPA. New series]. (Vol. 16): Volyn i Polissia u nevidomii epistoliarnii spadshchyni OUN $i$ UPA 1944 1954 rr. [Volhynia and Polissia in the Unknown Epistolary Heritage of the Organization of Ukrainian Nationalists and the Ukrainian Insurgent Army, 1944 - 1954]. Kyiv; Toronto: Litopys UPA, 1025 p. [in Ukrainian] 
Mudryk-Mechnyk, S. (1983). V zatiazhnii borotbi [In a Protracted Struggle]. Miunkhen: Ukrainske vydavnytstvo, 236 p. [in Ukrainian]

Mudryk-Mechnyk, S. (1984). Pochatok nevidomoho. Spohady 1945 - 1954 [The Beginning of the Unknown Memories 1945 - 1954]. Miunkhen: Ukrainske vydavnytstvo, 264 p. [in Ukrainian]

Mudryk-Mechnyk, S. (1989). Vyvchaimo voroha: Dopovidi, lektsii, rozdumuvannia i spomyny [Let's Study the Enemy: Reports, Lectures, Reflections, and Memoirs]. Miunkhen: Ukrainske vydavnytstvo, 317 p. [in Ukrainian]

Mykulyn, A. (1958). Kontsentratsiini tabory v Sovietskomu Soyuzi [Concentration Camps in the Soviet Union]. Without plase: Vydannia ZCh OUN, 216 p. [in Ukrainian]

Narodni Archiv Ceske Republiky [National Archives of the Czech Republic-NACR].

Sych, O. (2005). Referentura Pidsovietskykh Sprav - analitychnyi orhan Provodu Zakordonnykh Chastyn OUN [The Sub-Soviet Affairs Referentura, the Analytical Body of the Board of the Foreign Units of the Organization of the Ukrainian Nationalists]. Vyzvolnyi shliakh, 5, 66-83. [in Ukrainian]

Wysocki, R. (2003). Organizacja Ukraińskich Nacjonalistow w Polsce w latach (1929 - 1939): geneza, struktura, program, ideologia [Organization of the Ukrainian Nationalists in Poland in the years (1929 - 1939): origin, structure, program, ideology]. Lublin: Wydawnictwo Uniwersytetu Marii Curie Skłodowskiej, 433 p. [in Polish]

The article was received November 02, 2020. Article recommended for publishing 31/08/2021. 